\title{
An Analytical Study for Understanding the Degradation Process of a Late Period Mummy
}

\author{
Mina Magdy ${ }^{a^{*}}$, Mostafa Ismail ${ }^{\mathrm{a}}$, Yousry M. Issa ${ }^{\mathrm{b}}$, Gomaa Abdel-Maksoud ${ }^{\mathrm{c}}$, \\ Medhat Ibrahim ${ }^{\mathrm{d}}$ \\ a. National Museum of Egyptian Civilization, 17611 Cairo, Egypt \\ b. Chemistry Department, Faculty of Science, Cairo University, 12613 Giza, Egypt \\ c. Conservation Department, Faculty of Archaeology, Cairo University, 12613 Giza, Egypt \\ d. Spectroscopy Department, Physics Division, National Research Center, 12622 Giza, Egypt
}

\section{HIGHLIGHTS}

- Conducting multi-techniques to assess the preservation state of the mummy.

- Demonstrating the humidity role in the degradation of the materials.

- Manifesting the effect of packing on the mummy.

- Understanding the degradation process of a late period mummy.

\section{ARTICLE INFO}

Article History:

Received: 18 October 2020

Revised: 31 October 2020

Accepted: 14 December 2020

Available online: 21 December 2020

\section{Keywords:}

Egyptian mummy, degradation, humidity, analytical techniques, environmental conditions.

\section{GRAPHICAL ABSTRACT}

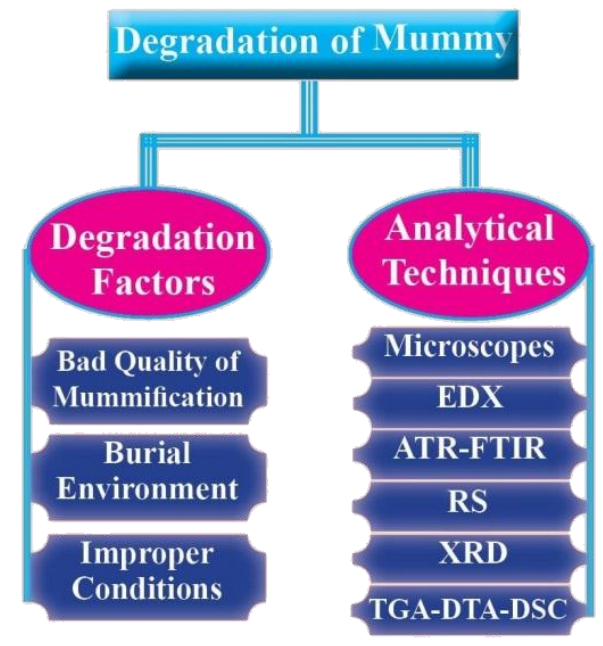

\begin{abstract}
Ancient mummies suffer from degradation as a result of the improper conditions which change both the chemical and physical properties of the materials. This study aims to explain the chemical changes of an Egyptian mummy dating back to the late period. Multiple analytical techniques have been executed to characterize the different components of the mummy: optical microscopy, stereo microscopy, scanning electron microscopy-energy dispersive X-ray spectroscopy, attenuated total reflection-Fourier transform infrared spectroscopy, Raman spectroscopy, X-ray diffraction, thermogravimetric analysis, differential thermal analysis, and differential scanning calorimetry.
\end{abstract}

\footnotetext{
* Corresponding author: minamagdy_2000@yahoo.com
} 
The results revealed that the Natron salt existed over the linen wraps with the presence of the mastic resin and beeswax as embalming materials. The incorrect packing method had a negative effect through which the surrounding humidity around the mummy's body accelerated the reaction between the water vapor and the mummy's components. The water molecules of humidity interacted with the Natron salt to form a basic medium, and the humid conditions promoted the microbial and insect activity. The analytical investigation showed the fabric embrittlement in the wrapping and the diagenetic alterations in the bone.

\section{Introduction}

Egyptian civilization is one of the earliest in history, and the ancient Egyptians recorded not only their writings but also their memories through mummification of their bodies. The ancient Egyptians believed in resurrection after death and made it necessary to preserve their bodies to the afterlife [1-5]. The mummification (artificial mummification) was practiced in Egypt from the Old Kingdom to the Christian era. The process of mummification took many years of experimentation throughout the historical ages using some methods, natural materials, and other agents until it reached perfection [1]. According to Herodotus, the embalmers had shown the family of the deceased wooden models of corpses so that they could choose the level of mummification they wanted. The mummification techniques were classified into three types. The first method, the most expensive method, was typically reserved for the royalty and very wealthy nobles. The second method was inferior to the first and did not include the wrapping of the body. The third method was the cheapest of all $[1,6]$. The main general features of the first class of the mummification process were:

1- Removal of the brain using a hooked rod passing through the ethmoid bone to the cranial cavity [3].

2- Removal of the viscera through an incision on the left side of the abdomen.

3- Dehydration of the body through burial of the body in heaps of Natron salts in order to avoid putrefaction or destruction of the tissues, and leaving the salted corpse for around 40 days. This was the main step in the mummification process due to the extraction of water from the body by the osmosis process. It depended on some factors such as the condition of the body prior to the Natron treatment, the compo- sition of the salt mixture, the ratio of $\mathrm{Na}$ tron volume to body volume, the re-use of salts for more than one body, and the duration of treatment in regard to the climate conditions [1-4].

4- Filling the thoracic and abdominal cavities with linen bags containing Natron salt, oils, and resin. After the removal of stuffing materials, the body was washed and dried with water and alcoholic solution.

5- Placing the extracted viscera into special jars (canopic jars) after the treatment with resin $[1,3]$.

6- Embalming the body with resin, gum, and wax for the protection from decomposition [1].

7- Wrapping the body with linen bandages that were sometimes adorned with amulets, decorated mask (cartonnage) and inscriptions [7].

8- Placing the mummy in a body-shaped container (coffin or sarcophagus), and there might be personal items along with the body [8].

The second method of mummification included the complete evisceration, the injection of cedar oil into the anus, and the treatment of the body with Natron salt. Once this was completed, the oil was drained off in which the intestine and the stomach came away, and the flesh was also desiccated. The third method of mummification included the removal of the stomach and internal organs through an abdominal incision on the left side of the body. The body cavities were sterilized with alcohol, and the whole body was then buried in Natron salt [1]. According to Herodotus, the three types of mummification could be practiced in the same area and period, depending on the social status of the deceased. The authors confirmed that the mummification process was lower in quality than in most of the late period mummies 
compared to the New Kingdom and Third Intermediate mummies. It can also be added that the quality of mummification reflects the state of preservation of the mummies. Although the mummification process aims to preserve the body from decay, the mummy's body is susceptible to degradation. The decomposition of mummification materials is a complex chain of events that results in changing the molecular composition of materials. It may be due to the mummification technique, the burial environment, or the storage conditions. The investigation process of the degradation aspects of a mummy helps conservators to design a preservation strategy.

Analysis and investigation are vital in the conservation field because they explain the mechanism of degradation and the state of preservation of a mummy, which can help conservators in setting a plan for the conservation treatment or preventive conservation. This study aims to understand the degradation process of an Egyptian mummy through assessing the state of a fabric wrapping and a small bone specimen of the mummy. A group of analytical techniques will be used to give information about the chemical structure and composition of the materials and to explain the degradation mechanism. Attenuated total reflection-Fourier transforms infrared spectroscopy (ATR-FTIR) and Raman spectroscopy (RS) will be employed to give information about the chemical structure of the materials. Optical microscopy (OM), stereo microscopy (SM), and scanning electron microscopy (SEM) will be used to detect the morphology of the fibers and illustrate the degradation aspects. Energy dispersive X-ray spectroscopy (EDX) will be applied to detect the elements of mineral content variation in the bone. X-ray diffraction spectroscopy (XRD) will be applied to determine the crystalline phases of the materials [9-12]. Thermo gravimetric analysis (TGA), differential thermal analysis (DTA), and differential scanning calorimetry (DSC) will be performed to observe the thermal behavior of the materials [13].

\section{Materials and methods}

\subsection{Archaeological mummy}

The studied mummy was discovered in the desert necropolis of Saqqara "Gisr ElMudir", Giza, Egypt, on January 12, 2010. It was then deposited in the wood restoration lab in Saqqara archaeological site with the registration number: G.M - F6 117. The mummy dates back to the late dynastic period of ancient Egypt (332-664 B.C.) [5]. the mummy was wrapped with ancient fabric strips and modern bandages in which the upper part was covered with the sponge, and the whole mummy was enclosed with the cardboard paper and polyethylene strips (Fig. $1)$. The mummies in the late period were characterized by the extensive use of resin in the body cavities, and there was more concern with the external appearance than the preservation of the body [2, 5, 14]. Intact fiber, powder fiber, and small bone (lumbar vertebra) samples were taken from the studied mummy.

\subsection{Instruments}

\subsubsection{Temperature/humidity meter}

Measurements of the temperature and humidity of the surrounding storage area were taken by Tenmars TM-183 (Tenmars Electronics Co., Taipei, Taiwan). The temperature range was $20-60{ }^{\circ} \mathrm{C}$ and the humidity range was $1-99 \%$ with the resolution of $\pm 0.1{ }^{\circ} \mathrm{C}$ and $\pm 0.1 \% \mathrm{RH}$, respectively.

\subsubsection{Optical microscopy (OM)}

The photographs were made with a Leica motorized light microscope system attached with a digital Camera Leica ICC50 HD (Leica DM750, Wetzlar, Germany).

\subsubsection{Stereo microscopy (SM)}

The photographs were taken with a Leica M216 stereo microscope equipped with a Leica DF C450 digital camera (Leica Microsystems, Heerbrugg, Switzerland). 
2.2.4. Field emission scanning electron microscopy-energy dispersive $X$ ray spectroscopy (FESEM-EDX)

The samples were examined with FESEM (Quanta FEG-250, FEI company, Eindhoven, Netherland) coupled with an EDX analysis unit (EDAX AMETEK analyzer). The analysis was performed at an accelerating voltage of $30 \mathrm{kV}$ and magnification $14 \mathrm{x}$ up to 1000000 with a resolution of $1 \mathrm{~nm}$.

\subsubsection{Attenuated total reflection- Fourier transform infrared spec- troscopy (ATR-FTIR)}

Mid Infrared (MIR) spectra were recorded with a Vertex 70 FTIR spectrometer (Bruker Optics, Ettlingen, Germany) equipped with a diamond ATR and DLaTGS detector accessories. The spectral range was from 600$4000 \mathrm{~cm}^{-1}$ and the resolution was $4 \mathrm{~cm}^{-1}$ with 16 scans.

\subsubsection{Raman spectroscopy (RS)}

Bruker Senterra spectrometer (Bruker Optics Inc., Billerica, Massachusetts, USA) equipped with $785 \mathrm{~nm}$ excitation laser source in the range 0.1 to $100 \mathrm{~mW}$. The spectral range was from $100-3000 \mathrm{~cm}^{-1}$ and was recorded at a resolution of $9 \mathrm{~cm}^{-1}$. The integration time was $10 \mathrm{~s}$ for each spectrum, and the exposure time was $1 \mathrm{~s}$ for every scan. The spectrometer was equipped with a thermoelectrically cooled charge-coupled device "CCD" detector, operating at $-65^{\circ} \mathrm{C}$.

\subsubsection{X-ray diffraction (XRD)}

Diffraction patterns were performed on Xray diffractometer (X'Pert PRO, PANalytical, Al-melo, Netherlands) using $\mathrm{Cu} \mathrm{K} \alpha$ radiation $\left(\lambda=1.54060 \mathrm{~A}^{\circ}\right)$ in the angular region of $2 \theta=4^{\circ}-80^{\circ}$. The instrument was operated at $40 \mathrm{kV}$, and X-ray diffraction pattern was recorded at the scanning speed of $8^{\circ} \mathrm{min}^{-1}$. The step size used was $0.02^{\circ}$ and the step time was $0.7 \mathrm{~s}$.

\subsubsection{Thermal analyses}

Thermo gravimetric Analysis (TGA), Differ ential Thermal Analysis (DTA), and Differential Scanning Calorimetry (DSC) of the samples were performed on simultaneous TGA/DSC and SDT Q600 (TA Instruments Inc., New Castle, DE, USA). The samples were heated from room temperature to 1000 ${ }^{\circ} \mathrm{C}$ at a rate of $10{ }^{\circ} \mathrm{C} \mathrm{min}{ }^{-1}$ using nitrogen gas with a flow rate of $30 \mathrm{mLmin}^{-1}$.

\section{Results and discussion}

The archaeological samples are complex materials and are associated with degradation products, so it is required to use highresolution techniques to provide good data about the materials used. The mummification in the late period was poorly preserved that could allow the autolysis and putrefaction of the body [5, 15]. The disintegration of soft tissues from the body and the disruption of the wrappings are signs of the bad mummification technique [16]. The mummy was buried in a sandy soil, and it is now near an agricultural land that could play a role in the degradation process. The mummy was stored in a crowded room with seventeen mummies in an uncontrolled surrounding environment. Additionally, the wooden roof did not prevent the rainwater from falling on the mummies' bodies. A portfolio of many analytical techniques is used to get information about the potential degradation of the materials.

\subsection{Measurement of temperature and humidity}

Measurements of the environmental conditions in the storage room were recorded; the temperature was $22.6{ }^{\circ} \mathrm{C}$, and the relative humidity was $55 \%$. These can be considered as good external environmental conditions in the storage area, so any degradation would appear as a result of internal interactions of the mummy materials with the outer packing sheets (sponge, cardboard, and polyethylene). These sheets act as an insulator of the mummy from the surrounding environment. After removing the packing layers, some aspects of deterioration were noticed (Figs. 1 and 2).

\subsection{Microscopy imaging}

OM photographs show nodes (transverse dislocations) and a narrow lumen within the fibers, which are distinctive of linen (Fig. 3) $[17,18]$. 

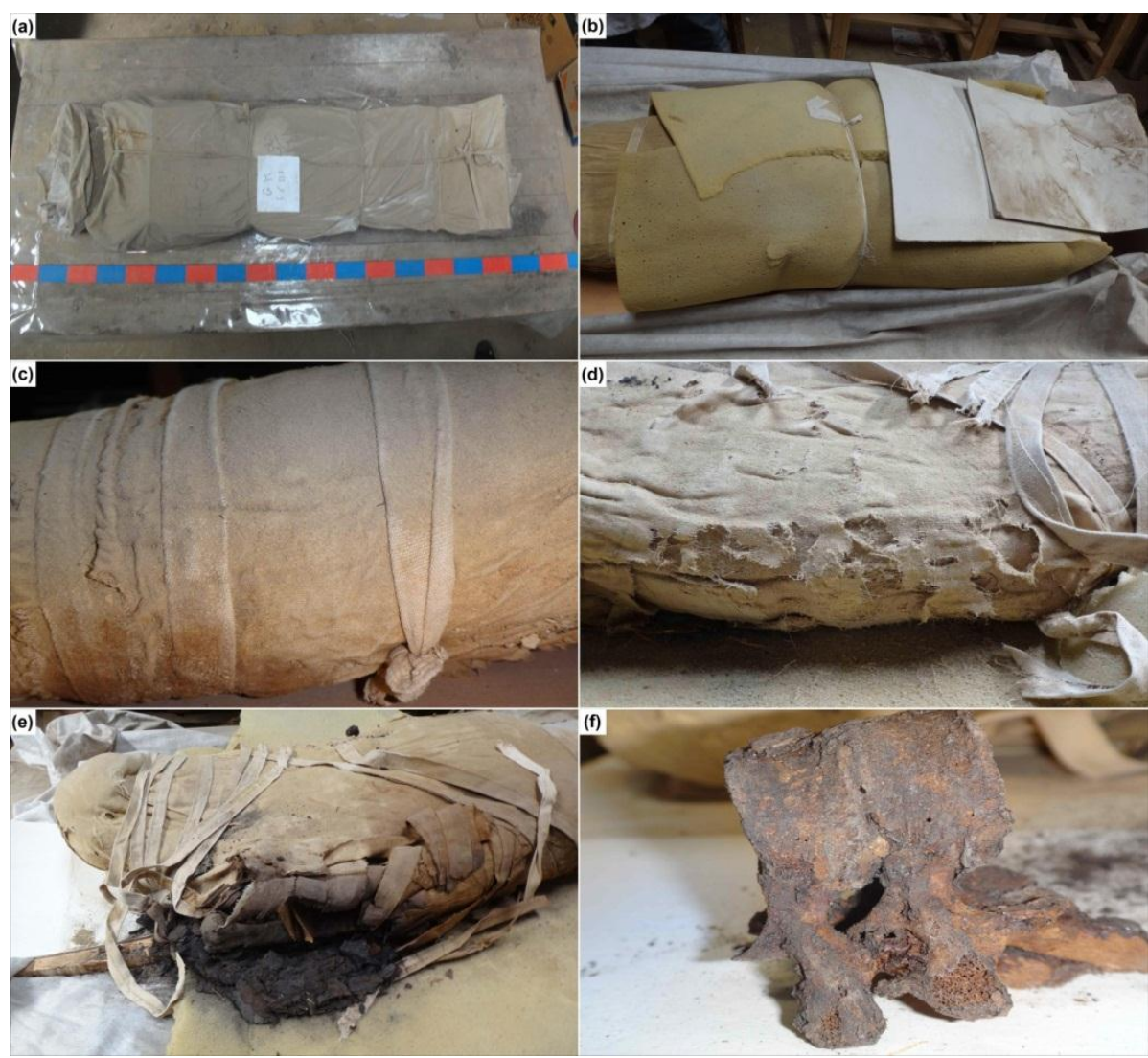

Fig. 1. A general image of the mummy shows the packing with polyester and sponge coverage (a, b) and the deterioration aspects of the mummy (c-f)

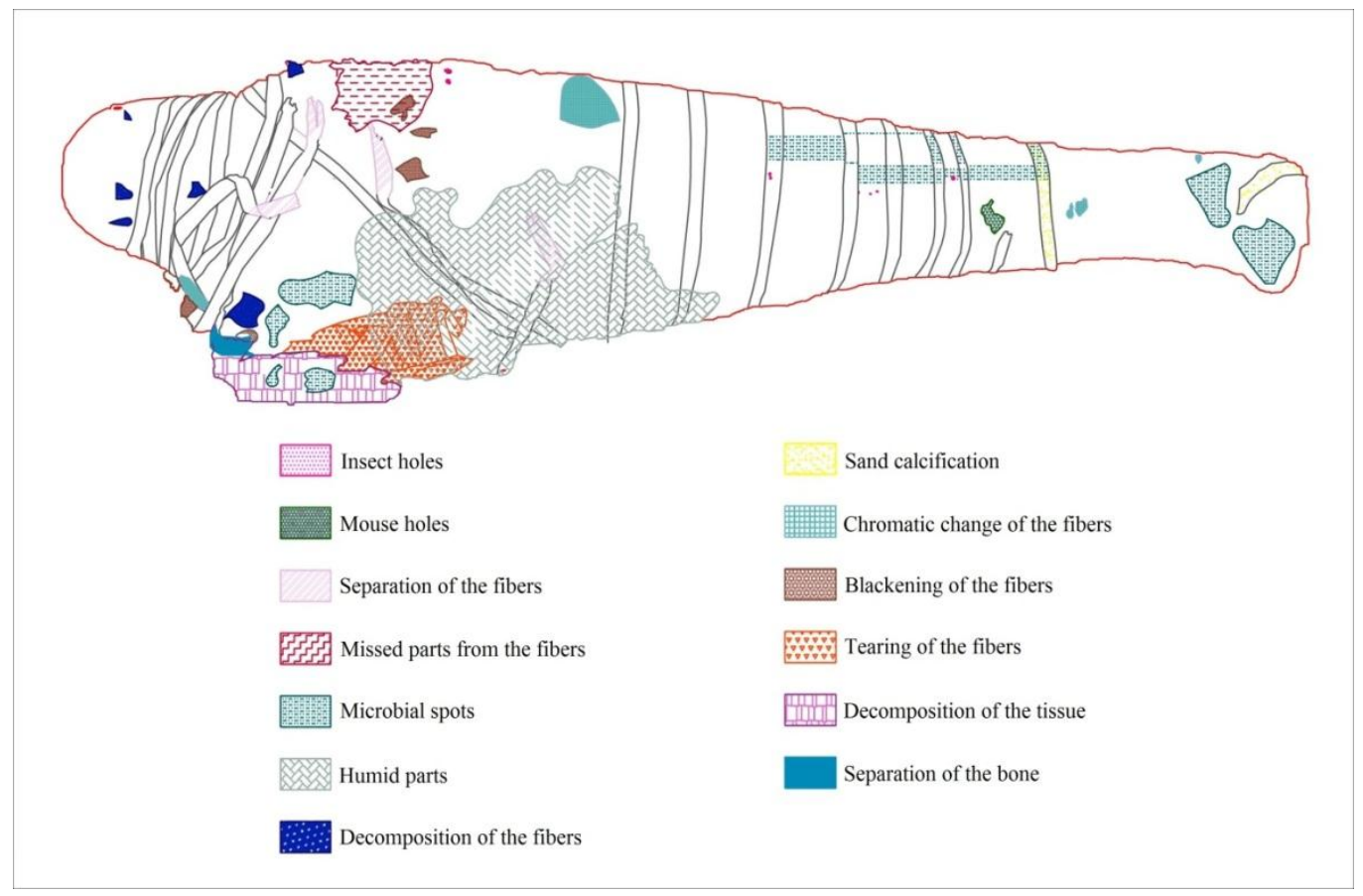

Fig. 2. AutoCAD image shows the degradation aspects of the mummy. 
The optical photographs reveal breaking the fibers, and the stereo photograph exhibits degradation of these fibers into powder form (Figs. 3 and 4). SM and SEM show brushlike fractures of the intact fibers with salt accumulation over the wraps, and these demonstrate the fragmentation process of the cellulose chains and the breakdown of the interchain linkages (Figs. 4 and 5) [19]. When the soluble salts crystallized upon fluctuation of the humidity and evaporation of the water molecules, there was an increase in the volume and pressure throughout the porous layers of degraded fibers, resulting in severe damage of the wrapping (Fig. 1) [20, 21]. EDX microanalysis of intact fiber sample detects $\mathrm{Na}, \mathrm{Cl}, \mathrm{S}, \mathrm{K}, \mathrm{Al}, \mathrm{Mg}$, and Si elements, probably referring to the presence of salts (Table 1) [1-3]. The salt has a hygroscopic character and could absorb water vapor from ambient humidity to yield a basic medium [1]. The humid medium could create a good environment for the growth of microorganisms and biodeterioration of the mummy's body, and the SEM photographs show agglomeration of the fungi hyphae (Fig. 5) [22]. The humid conditions en-couraged the growth of insects, and thus there are many holes within the fibers [2]. The microbial activity assisted the hydrolysis of cellulose through enzymatic cleavage of the glycosidic bonds [23]. The intra-chain scission of cellulose denotes the deterioration of the physical properties of wraps with reduction of the tensile strength and then the breakdown of the long chains to short chains, and this appears obvious in the powder form of the wraps to address the fiber damage [24]. The penetration of water vapor from the humidity inside the bone allowed carbonate ions to absorb within the mineral phase and recrystallize the apatite lattice. This process used carbon dioxide gas from the complete degradation of the wrapping in the basic medium into a powder form. It facilitated the hydroxyapatite dissolution and thus reduced the acidity to create a good environment for the microorganisms [25-28]. In the same context, SM photographs and SEM microphotographs show an increase of the bone matrix (larger than $8 \mathrm{~nm}$ ) that may illustrate the dissolution of the mineral phase and exceed the bone micro-porosity (Figs. 4 and 5) [27-29]. SEM photographs highlight the presence of many pore spaces on the bone surface, supporting the penetration of microorganisms into the bone matrix and bio-degradation of the collagen (Fig. 5). The diagenesis process of the bone is associated with the loss of collagen phase and bone rigidity due to the depolymerization and breaking down of the protein to peptide units $[21,27,28,30]$. Semiquantitative EDX analysis had been applied to give information about the state of bone; the average $\mathrm{Ca} / \mathrm{P}$ ratio of double measurements was 1.60 as a type of reproducibility measurement, and this value is a deviation from the ideal theoretical case (1.67) (Table 1) $[31,32]$. The non-stoichiometry of the apatite phase may indicate the chemical change in the mineral matrix upon the diagenesis process of the bone by the substitution and recrystallization of $\mathrm{Ca}^{2+}$ ions of apatite with $\mathrm{Na}^{+}$or $\mathrm{Mg}^{2+}$ impurities ions in the crystal vacancies or surface adsorption of phosphate ions through forming stronger bonds with calcium sites than the carbonate ions [29]. The digital photograph of another bone sample, a segment from the fractured body, shows severe degradation of the skeletal body as a result of the diagenetic alterations and malfunction of collagen (Fig. 1f).

\subsection{Vibrational spectroscopy}

The infrared spectra of intact and powder samples demonstrate the characteristic bands of carbonate, sulfate, and quartz of the chemical composition of the Natron salt $\left(\mathrm{Na}_{2} \mathrm{CO}_{3}\right.$, $\mathrm{NaHCO}_{3}, \mathrm{NaCl}, \mathrm{Na}_{2} \mathrm{SO}_{4}$, and quartz) (Fig. 6 and Table 2) [33, 34]. The intact fiber manifests an infrared band at $3271 \mathrm{~cm}^{-1}$, which may be assigned to cellulose $\mathrm{I}_{\beta}$, indicating the crystallinity of the cellulose fiber (Fig. 6 and Table 2) $[35,36]$. The more hydrogen bonds within the cellulose chains, the greater packing with better mechanical properties and this appears clearly in the intact and powder fibers [36].

The increase of Raman intensity of bending $(\mathrm{C}-\mathrm{C})$ of the powder sample near $400 \mathrm{~cm}^{-1}$ indicates the more free movement of cellulose rings as a result of the cellulolytic process $[37,38]$. The bone has infrared bands of collagen protein at $3256,1545,1439$, 


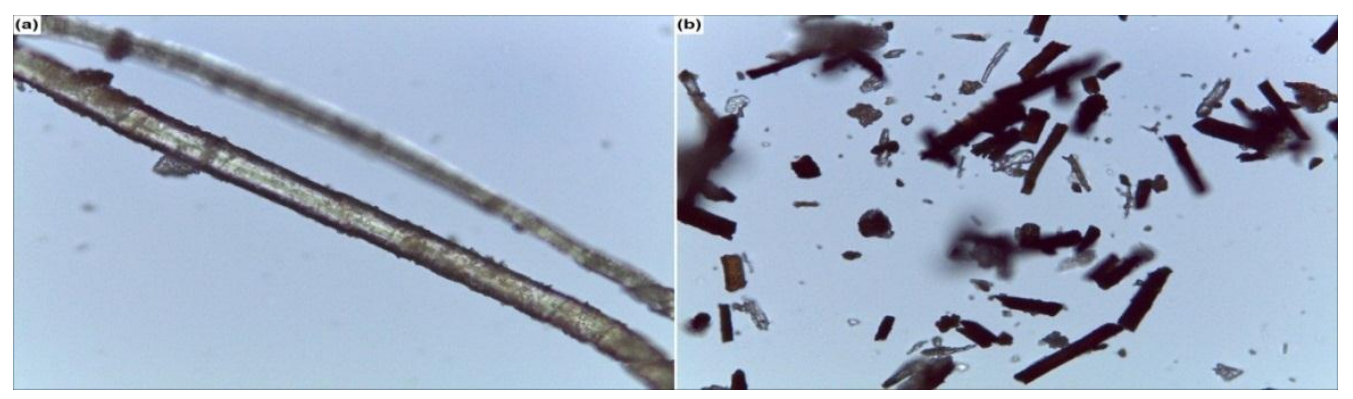

Fig. 3. OM photographs of: intact sample shows the texture of linen fibers (a) and powder sample shows the degradation of the fibers $(b)$.

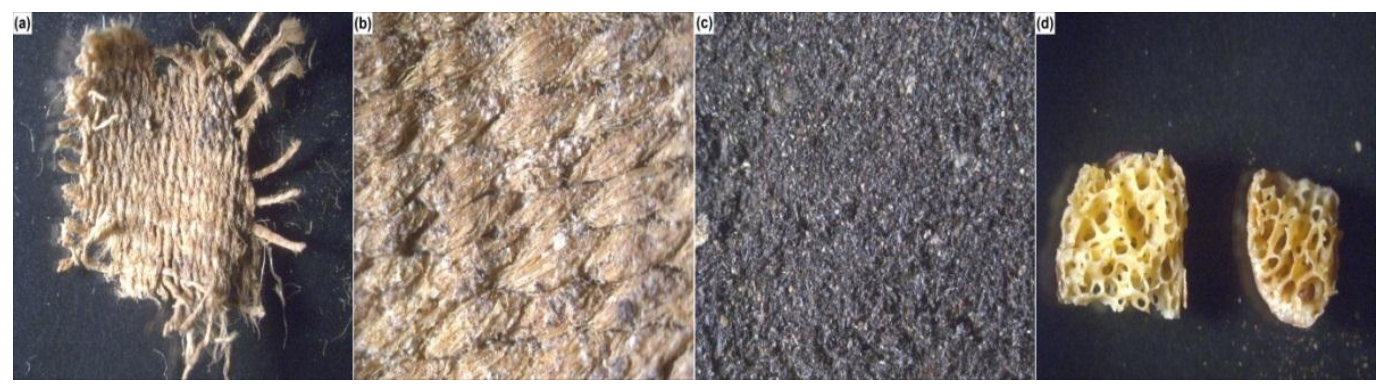

Fig. 4. SM photographs of: intact fiber sample shows the consistency of the fibers (a), intact fiber sample shows the accumulation of salts on the fiber surface (b), powder fiber sample shows the grains of the degraded fibers(c), and bone sample shows the physical state of the bone matrix (d).

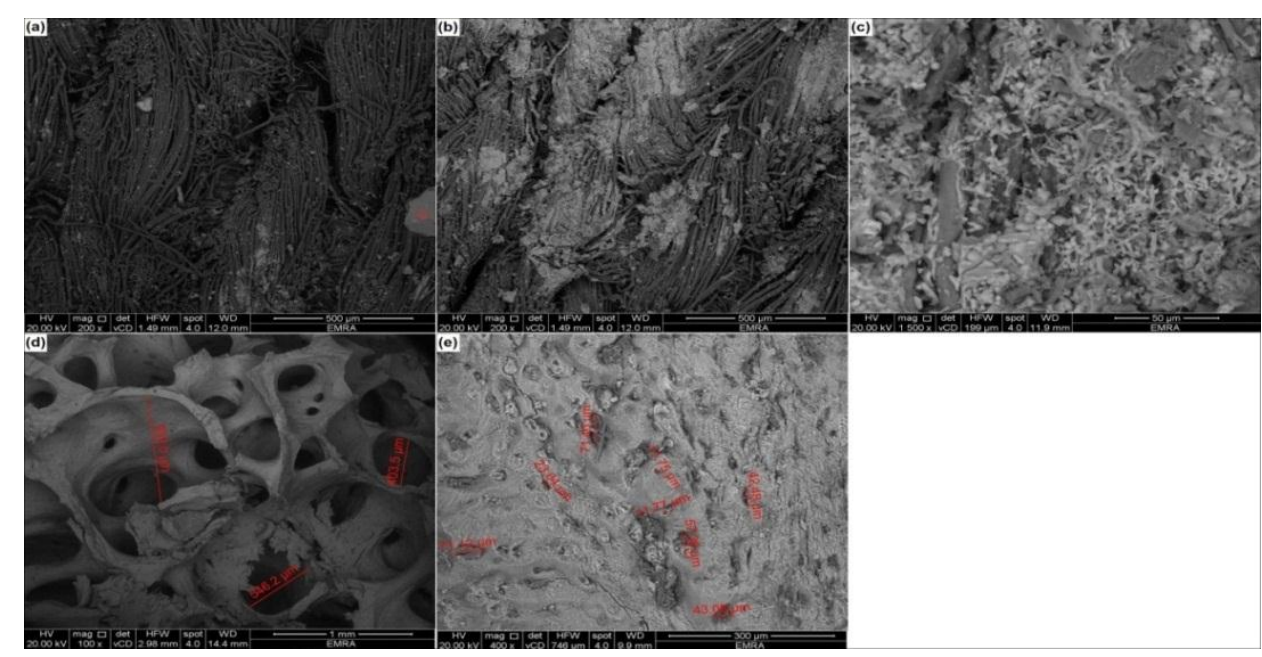

Fig. 5. SEM microphotographs of: intact fiber sample shows the fracture of the fibers (a), intact fiber sample shows the accumulation of the salts (b), intact fiber sample shows the growth of the microorganisms (c), bone sample shows the increase of the bone matrix (d), and bone sample shows the increase of the micro-porosity of the bone surface (e). 
Table 1. Elemental EDX microanalysis (atomic percentage of elements) of the samples.

\begin{tabular}{ccc}
\hline Element & $\begin{array}{c}\text { Intact fiber } \\
\text { sample }\end{array}$ & $\begin{array}{c}\text { Bone sample } \\
\text { (second } \\
\text { measurement) }\end{array}$ \\
\hline O K & 48.13 & $40.01(40.33)$ \\
$\mathrm{C} \mathrm{K}$ & 25.37 & $30.07(28.12)$ \\
$\mathrm{Ca} \mathrm{K}$ & 10.80 & $12.04(14.02)$ \\
$\mathrm{N} \mathrm{K}$ & - & $10.21(8.87)$ \\
$\mathrm{P} \mathrm{K}$ & 6.34 & $7.66(8.65)$ \\
$\mathrm{Na} \mathrm{K}$ & 4.19 & - \\
$\mathrm{S} \mathrm{K}$ & 1.73 & - \\
$\mathrm{Cl} \mathrm{K}$ & 1.61 & - \\
$\mathrm{K} \mathrm{K}$ & 0.65 & - \\
$\mathrm{Mg} \mathrm{K}$ & 0.59 & - \\
$\mathrm{Si} \mathrm{K}$ & 0.37 & - \\
$\mathrm{Al} \mathrm{K}$ & 0.23 & - \\
\hline
\end{tabular}

and $1230 \mathrm{~cm}^{-1}$ and hydroxyapatite $\left[\mathrm{Ca}_{10}\right.$ $\left.\left(\mathrm{PO}_{4}\right)_{6}(\mathrm{OH})_{2}\right]$, the mineral component of the bone, for $\mathrm{v}\left(\mathrm{PO}_{4}\right)^{3-}$ at $974 \mathrm{~cm}^{-1}$ (Fig. 6 and Table 2) [39-42]. It also has Raman bands at $1244 \mathrm{~cm}^{-1}$ of collagen protein and 585 $\mathrm{cm}-1$ of phosphate ions (Fig. 7 and Table 3 ) $[43,44]$. The absence of the vibrational infrared and Raman bands of the amide I $(v \mathrm{CONH})$ may indicate the loss of the collagen skeleton as a sign of the diagenetic modifications [45, 46]. The infrared spectrum reveals absorption bands at 1076, $872 \mathrm{~cm}^{-1}$, and the Raman spectrum exhibits a high intensity of the bands at 1093, 710, $156 \mathrm{~cm}^{-1}$ that refer to calcium carbonate and the existence of which illustrates the absorption of carbonate ions of Natron salt (Figs. 6 and 7) [42, 43, 47].

The samples were attached to resin particles, and the infrared spectra reveal a $\delta(\mathrm{C}-\mathrm{H})$ band at $1202-1205 \mathrm{~cm}^{-1}$, which refers to the category of triterpenoid resin. Furthermore, the absorption bands of the fingerprint region at 1157 and $1156 \mathrm{~cm}^{-1}$ belong to the mastic resin (Pistacia lentiscus) that was commonly used in the mummification in ancient Egypt (Fig. 6 and Table 2) [48]. The samples have characteristic Raman bands of mastic resin at 858, 600, 307, and $305 \mathrm{~cm}^{-1}$ (Table 3) [49]. Although the mummy's body was anointed with the mastic resin to form a waterresistant seal, there are infrared bands of the intermolecular bound water at 1620-1628 $\mathrm{cm}^{-1}$. A broadening of the stretching infrared bands of $(\mathrm{O}-\mathrm{H})$ of linen fibers and $(\mathrm{N}-\mathrm{H})$ of the bone may denote hydrogen bonding between the molecules (Fig. 6) [50, 51] The presence of infrared bands in the bone spectrum at 2955 and $2854 \mathrm{~cm}^{-1}$ are characteristic of wax material in the sample, and there is also a characteristic band at $1175 \mathrm{~cm}^{-1}$ that may indicate the ester of the beeswax (Fig. 6 and Table 2) [52]. The powder fiber sample contains an infrared band at $2968 \mathrm{~cm}^{-1}$, and this shift of stretching $(\mathrm{C}-\mathrm{H})$ may manifest the degradation of hydrocarbon chains with the aging of the mummy. The beeswax was used as an embalming material to preserve the corpses or as a bath to soak the wrapping in the later periods of Egyptian history [1, 50].

\subsection{X-ray diffraction}

The diffractogram of the intact fiber sample shows a characteristic reflection pattern at $22.8^{\circ} 2 \theta$ that is assigned to the (002) crystallographic plane, while the powder fiber sample exhibits $18.1^{\circ} 2 \theta$ that is assigned to the amorphous phase $[19,36]$. The high intensity of these peaks refers to the preferred orientation of the crystals within the fibers. This reflects the impact of the degradation of the powder sample with a complete decomposition of the crystalline cellulose to an amorphous domain and a loss of the fiber rigidity. The XRD pattern of the bone sample shows peaks at $25.7^{\circ}, 31.7^{\circ}, 39.7^{\circ}, 46.5^{\circ}, 49.4^{\circ}$, and $53.1^{\circ}$ that attribute to Miller's indices of hexagonal hydroxyapatite $(002,211,310$, 222,213 and 004), and there is also a peak at $31.7^{\circ}$ (006) of calcium carbonate (Fig. 8) $[47,53]$. This may infer the dissolution of bone hydroxyapatite and the remineralization or recrystallization of carbonate crystals in the form of B-type carbonate apatite $\left[\mathrm{Ca}_{10}\left(\mathrm{PO}_{4}\right)_{3}\left(\mathrm{CO}_{3}\right)_{3}(\mathrm{OH})_{2}\right]$ [54-56]. The broad band at $31.7^{\circ}$ refers to the imperfection or distortion of the hydroxyapatite crystal lattice resulting from the introduction of trigonal planar $\mathrm{CO}_{3}{ }^{2-}$ ions to occupy the crystal vacancies of the tetrahedral $\mathrm{PO}_{4}{ }^{3-}$ ions $[31,57]$. 


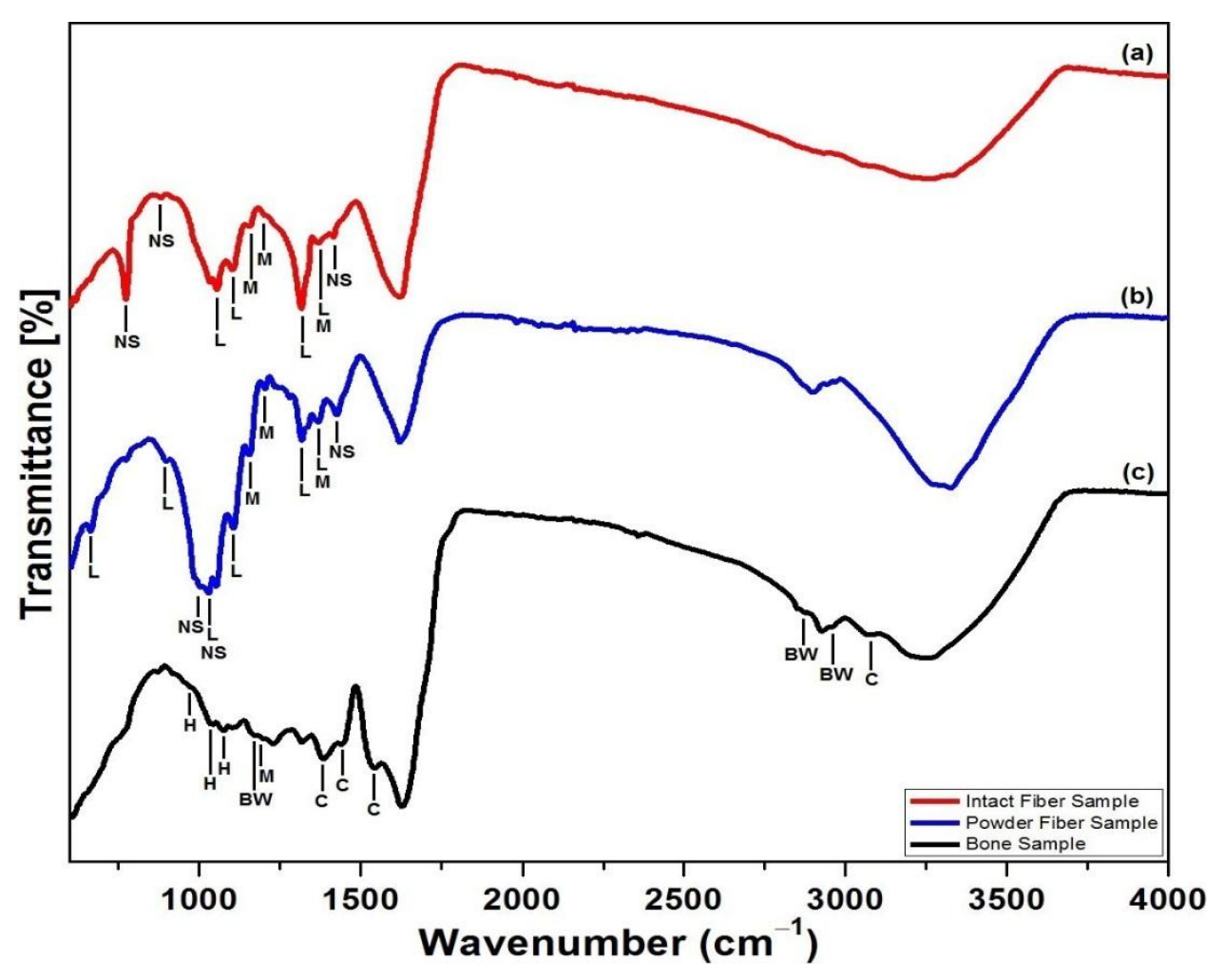

Fig. 6. Infrared spectra of intact fiber sample (a), powder fiber sample (b), and bone sample (c). Legends of the spectra are: beeswax (BW), collagen protein (C), hydroxyapatite $(\mathrm{H})$, linen fibers $(\mathrm{L})$, Natron salt (NS), and mastic resin (M).
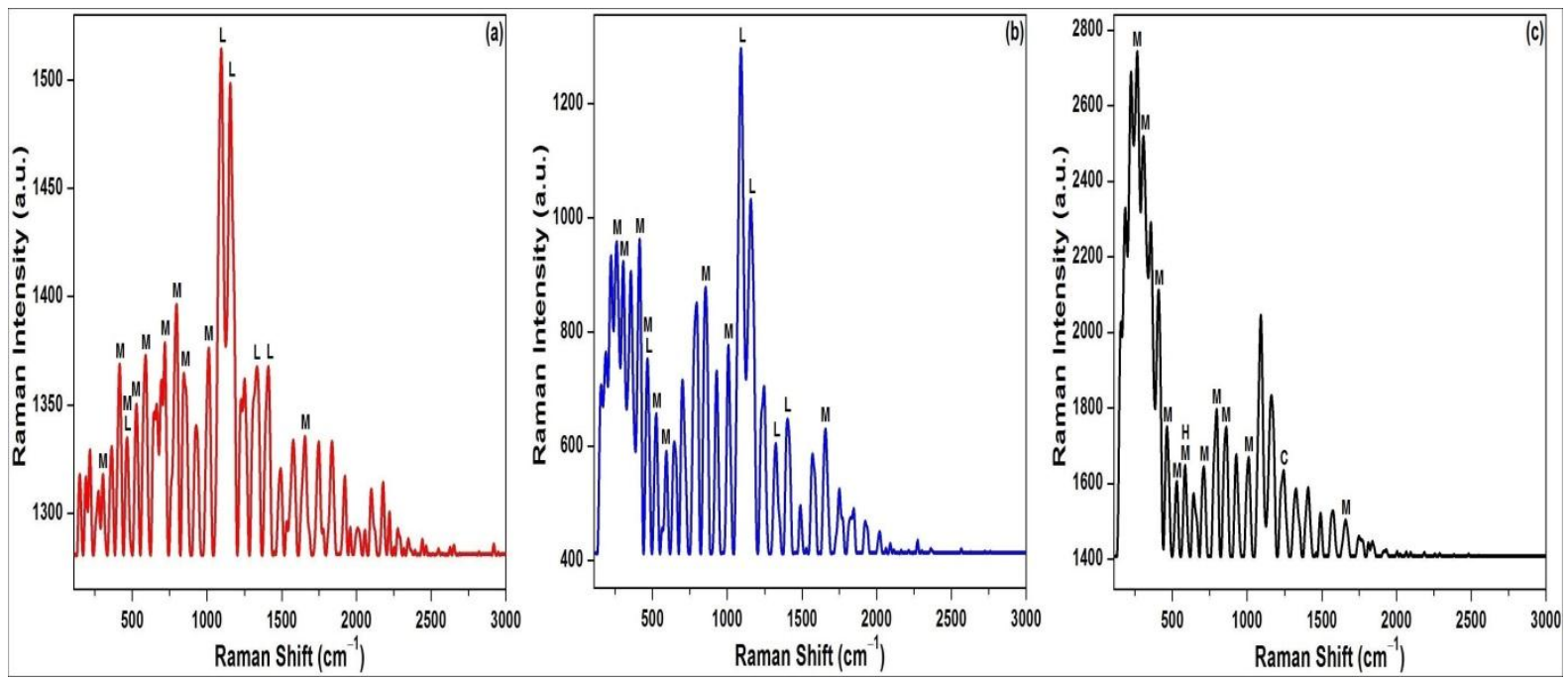

Fig. 7. Raman spectra of intact fiber sample (a), powder fiber sample (b), and bone sample (c). The materials are marked with labels: collagen protein $(C)$, hydroxyapatite $(\mathrm{H})$, linen fibers $(\mathrm{L})$, and mastic resin $(\mathrm{M})$. 
Table 2. Infrared bands assignment of the mummification samples.

\begin{tabular}{cl}
\hline Sample type & \multicolumn{1}{c}{ Infrared bands $\left(\mathbf{c m}^{-\mathbf{1}}\right)$} \\
\hline Intact fiber sample & \\
Linen fibers & $3331 \mathrm{v}(\mathrm{O}-\mathrm{H}), 1369,1315 \delta(\mathrm{C}-\mathrm{H}), 1103,1055,1032$ \\
& $\mathrm{v}(\mathrm{C}-\mathrm{O}), 881 \mathrm{v}(\mathrm{C}-\mathrm{O}-\mathrm{C}), 662,602 \delta(\mathrm{O}-\mathrm{H})$ \\
& $1416 \mathrm{v}\left(\mathrm{CO}_{3}{ }^{2-}\right), 1055 \mathrm{v}\left(\mathrm{Si}^{-} \mathrm{O}\right), 881 \delta\left(\mathrm{CO}_{3}{ }^{2-}\right), 771$ \\
Natron salt & $\delta(\mathrm{Si}-\mathrm{O}-\mathrm{Si}), 635,617 \delta\left(\mathrm{SO}_{4}{ }^{2-}\right)$ \\
& $2934 \mathrm{v}(\mathrm{C}-\mathrm{H}), 1622 \delta(\mathrm{O}-\mathrm{H}), 1369 \delta(\mathrm{C}-\mathrm{H}), 1205,1157$ \\
Mastic resin & $v(\mathrm{C}-\mathrm{O}), 642 \delta(\mathrm{C}-\mathrm{H})$ \\
& $3327 \mathrm{v}(\mathrm{O}-\mathrm{H}), 1369,1317 \delta(\mathrm{C}-\mathrm{H}), 1107,1053,1028,1005$, \\
Powder fiber sample & $987 \mathrm{v}(\mathrm{C}-\mathrm{O}), 899 \mathrm{v}(\mathrm{C}-\mathrm{O}-\mathrm{C}), 663 \delta(\mathrm{O}-\mathrm{H})$ \\
Linen fibers & $\left.1425 \mathrm{v}(\mathrm{CO})^{2-}\right), 1053 \mathrm{v}(\mathrm{Si}-\mathrm{O}), 1005 \mathrm{v}\left(\mathrm{HCO}_{3}{ }^{-}\right), 773$ \\
& $\delta(\mathrm{Si}-\mathrm{O}-\mathrm{Si})$ \\
Natron salt & $2943 \mathrm{v}(\mathrm{C}-\mathrm{H}), 1620 \delta(\mathrm{O}-\mathrm{H}), 1369 \delta(\mathrm{C}-\mathrm{H}), 1203,1155$ \\
& $v(\mathrm{C}-\mathrm{O})$ \\
Mastic resin & \\
Bone sample & $3256,3072 \mathrm{v}(\mathrm{N}-\mathrm{H}), 2928,2878 \mathrm{v}(\mathrm{C}-\mathrm{H}), 1545 \delta(\mathrm{N}-\mathrm{H})_{\text {amide II }}$, \\
Collagen protein & $1439,1385 \delta(\mathrm{C}-\mathrm{H}), 1230 \mathrm{v}(\mathrm{C}-\mathrm{N})$ amide III \\
Hydroxyapatite & $1076,1041,974 \mathrm{v}(\mathrm{PO})_{4}^{3-}, 629 \delta(\mathrm{O}-\mathrm{H}), 608 \delta\left(\mathrm{PO}_{4}\right)^{3-}$ \\
Mastic resin & $2928,2854 \mathrm{v}(\mathrm{C}-\mathrm{H}), 1628 \delta(\mathrm{O}-\mathrm{H}), 1202 \mathrm{v}(\mathrm{C}-\mathrm{O})$ \\
Beeswax & $2955,2854 \mathrm{v}(\mathrm{C}-\mathrm{H}), 1175 \mathrm{v}(\mathrm{C}-\mathrm{O})$ \\
\hline
\end{tabular}

Table 3. Raman bands assignment of the mummification samples.

\begin{tabular}{|c|c|}
\hline Sample type & Infrared bands $\left(\mathrm{cm}^{-1}\right)$ \\
\hline \multicolumn{2}{|l|}{ Intact fiber sample } \\
\hline Linen fibers & $\begin{array}{l}2919 v(\mathrm{C}-\mathrm{H}), 1410,1334 \delta(\mathrm{C}-\mathrm{H}), 1157 v(\mathrm{C}-\mathrm{C}), 1096 \\
v(\mathrm{C}-\mathrm{O}-\mathrm{C}), 466 \delta(\mathrm{C}-\mathrm{C}-\mathrm{O})\end{array}$ \\
\hline Mastic resin & $\begin{array}{l}1656 v(\mathrm{C}=\mathrm{C}), 1013 v(\mathrm{C}-\mathrm{C}), 846 v(\mathrm{C}-\mathrm{C}-\mathrm{O}), 797,719,664 \\
590 v(\mathrm{C}-\mathrm{C}), 528 \delta(\mathrm{C}-\mathrm{C}-\mathrm{O}), 466,416,305 \delta(\mathrm{C}-\mathrm{O})\end{array}$ \\
\hline \multicolumn{2}{|l|}{ Powder fiber sample } \\
\hline Linen fibers & $\begin{array}{l}2724 v(\mathrm{C}-\mathrm{H}), 1403 \delta(\mathrm{C}-\mathrm{H}), 1324 \delta(\mathrm{C}-\mathrm{O}-\mathrm{H}), 1159 v(\mathrm{C}-\mathrm{C}) \\
1093 v(\mathrm{C}-\mathrm{O}-\mathrm{C}), 467 \delta(\mathrm{C}-\mathrm{C}-\mathrm{O})\end{array}$ \\
\hline Mastic resin & $\begin{array}{l}1657 v(\mathrm{C}=\mathrm{C}), 1009 v(\mathrm{C}-\mathrm{C}), 855 v(\mathrm{C}-\mathrm{C}-\mathrm{O}), 593 v(\mathrm{C}-\mathrm{C}) \\
525 \delta(\mathrm{C}-\mathrm{C}-\mathrm{O}), 467,415,305,260 \delta(\mathrm{C}-\mathrm{O})\end{array}$ \\
\hline \multicolumn{2}{|l|}{ Bone sample } \\
\hline Collagen protein & $1244 \mathrm{v}(\mathrm{C}-\mathrm{N})_{\text {amide III }}$ \\
\hline Hydroxyapatite & $585 \delta\left(\mathrm{PO}_{4}\right)^{3-}$ \\
\hline Mastic resin & $\begin{array}{l}1658 v(\mathrm{C}=\mathrm{C}), 1011 v(\mathrm{C}-\mathrm{C}), 860 v(\mathrm{C}-\mathrm{C}-\mathrm{O}), 797,710,585 \\
v(\mathrm{C}-\mathrm{C}), 529 \delta(\mathrm{C}-\mathrm{C}-\mathrm{O}), 464,408,307,265 \delta(\mathrm{C}-\mathrm{O})\end{array}$ \\
\hline
\end{tabular}


The sharp peaks of apatite may report infilling of the carbonate in the voids and reduction of the crystallite size, thus increase of the surface area to more interaction with the exogenous ions and degradation of the bone [58].

\subsection{Thermal analyses}

The thermal profile of mummification materials is complicated with multiple degradation pathways within the one sample. The TGA curve of the intact fiber sample shows four steps of weight loss. The first weight loss of $5.05 \%$ (in the temperature range 47 $131{ }^{\circ} \mathrm{C}$ ) is attributed to the moisture content within the cellulose fibers and the sodium bicarbonate of Natron salt. The second weight loss of $18.96 \%$ (in the temperature range 209-367 ${ }^{\circ} \mathrm{C}$ ) means the decomposition of the organic skeleton of cellulose. The third weight loss of $10.10 \%$ (in the temperature range $430-540{ }^{\circ} \mathrm{C}$ ) may refer to the degradation of the mastic resin. The fourth weight loss of $23.54 \%$ (in the temperature range $601-1000{ }^{\circ} \mathrm{C}$ ) may refer to the sodium sulfate of mummification salt [36,59-62]. The DTA curve of the intact sample shows three endothermic peaks at 32,76 , and $534{ }^{\circ} \mathrm{C}$, and the DSC curve manifests three phase change peaks with maxima at 31,71 , and $534{ }^{\circ} \mathrm{C}$ due to the loss of hygroscopic and hydroxyl water [63]. The TGA curve of the powder fiber sample shows three steps of weight loss. The first weight loss of $3.87 \%$ (in the temperature range $34-79{ }^{\circ} \mathrm{C}$ ) is due to the absorbed water from the surrounding environment, the sodium bicarbonate of Natron salt, and the embalming beeswax. The second weight loss of $36.0 \%$ (in the temperature range $210-356^{\circ} \mathrm{C}$ ) may refer to the combustion of cellulose. The third weight loss of $19.22 \%$ (in the temperature range $412-1000{ }^{\circ} \mathrm{C}$ ) may refer to the decomposition of mastic resin and sodium sulfate of mummification salt. The DTA curve of the powder sample exhibits two endothermic peaks at 56 and $322{ }^{\circ} \mathrm{C}$, and the
DSC curve shows one phase change peak at $62{ }^{\circ} \mathrm{C}$ (Fig. 9). The thermal curves show that the intact fiber sample decomposes at a higher temperature compared to the powder sample [64]. The more order regularity of the intact fibers acts as a barrier to heat transfer with higher thermal stability rather than the degraded powder fibers [36].

The TGA curve of the bone sample shows three steps of weight loss. The first weight loss of $6.02 \%$ (in the temperature range 42 $163{ }^{\circ} \mathrm{C}$ ) refers to the melting of the beeswax and the dispersion of the water molecules throughout the bone molecules. The second weight loss of $25.71 \%$ (in the temperature range $197-502{ }^{\circ} \mathrm{C}$ ) may refer to the pyrolysis of organic collagen protein and mastic resin. The third weight loss of $5.60 \%$ (in the temperature range $705-1000{ }^{\circ} \mathrm{C}$ ) may be attributed to the decomposition of the inorganic bone minerals (calcium carbonate and hydroxyapatite) $[65,66]$. The DTA curve shows two broad endothermic peaks at 312 and 909 ${ }^{\circ} \mathrm{C}$, which refer to the chemically bound water and the mineral phase of the bone matrix, respectively. The DSC curve of the bone sample shows two broad phase change peaks at 88 and $909^{\circ} \mathrm{C}$ that may be attributed to the dehydration of the lattice water and the decomposition of the mineral phase of the bone matrix, respectively (Fig. 9) [67]. The broad band of phase transition of the mineral compounds may report the partial crystallinity of the mineral matrix with a different size distribution of the crystallites [68]. To sum up, the tight packing method of the mummy may be one of the factors that facilitated the degradation and assisted the flourishing of the microorganisms within the mummy's body.

The awareness of the conservators with the risks of incorrect preservation procedures is very crucial through conducting the preventive plan according to the object state and the standard precautions. 

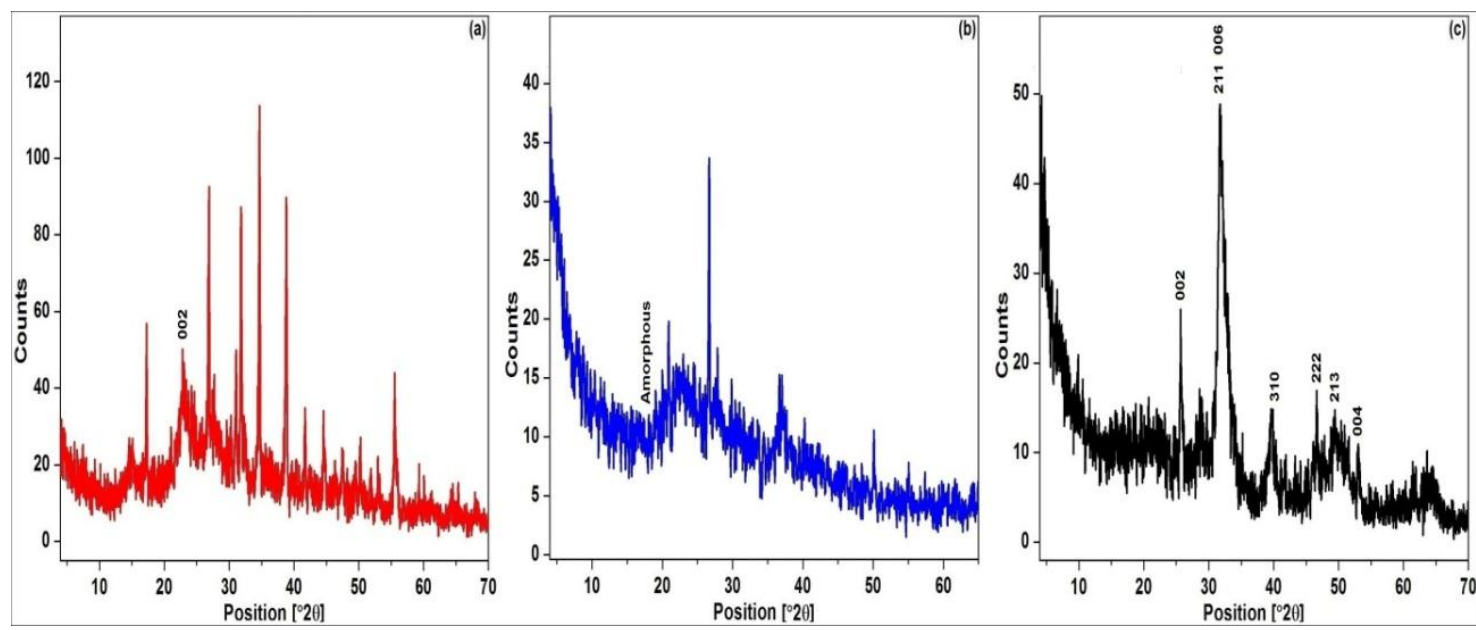

Fig. 8. XRD pattern of intact fiber sample (a), powder fiber sample (b), and bone sample (c).
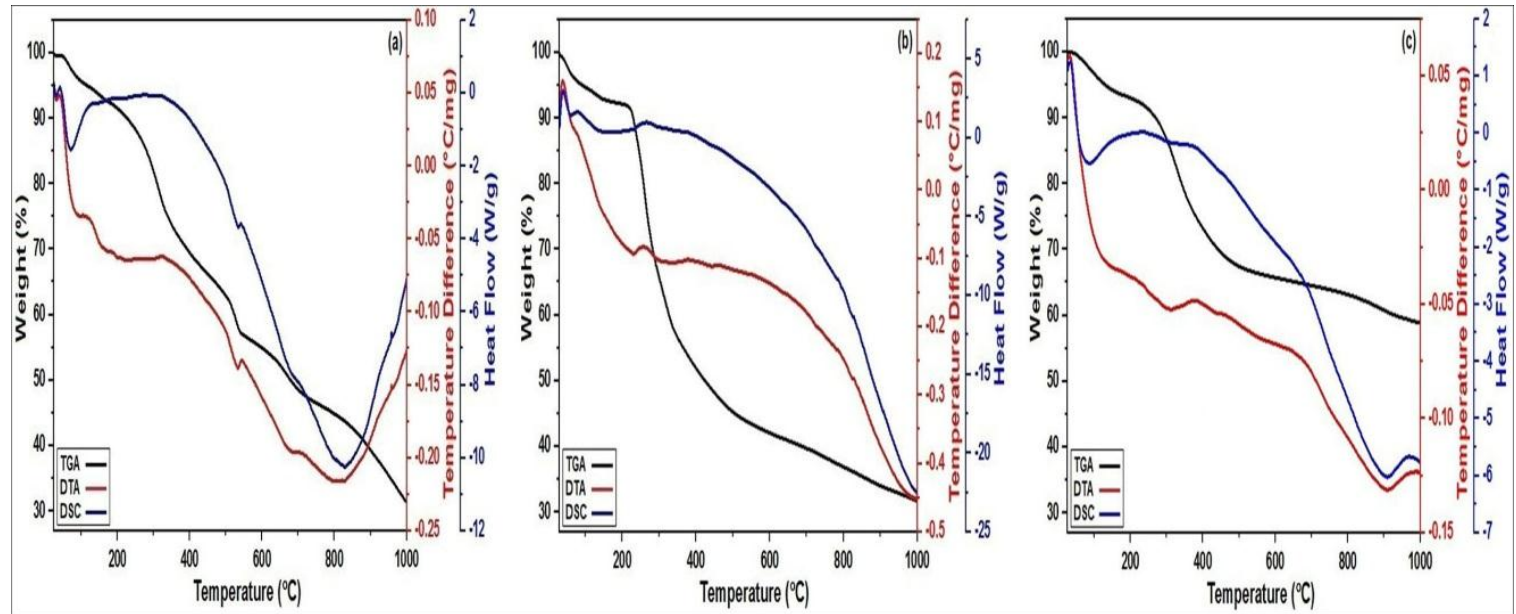

Fig. 9. Thermal curves (TGA, DTA, and DSC) of intact fiber sample (a), powder fiber sample (b), and bone sample (c). 


\section{Conclusion}

The degradation of the mummy's body arose from a variety of interrelated factors, including the bad quality of the mummification technique, the geographical region of the burial environment, and the poor facilities of the storage area. The tight packing procedures increased the water vapor content around the mummy's body. The humidity had a pronounced effect on the mummy, as the water molecules reacted with the mummification salts forming a basic medium that catalyzed the growth of the fungi. There were insect and mouse holes, which created a good connection with the surrounding environment, resulting in the deterioration of the materials. Multi-disciplinary techniques have been applied to clarify the state of materials and understand the degradation process. SEM exhibited the accumulation of salts, the growth of microorganisms, and the increase of surface pores of the bone matrix. Infrared and Raman spectra showed the degradation features of the wraps and the bone specimen. XRD pattern revealed the low crystalline content of the powder cellulose fibers and the low crystalline inorganic phase of the bone matrix. Thermal analyses revealed the impact of absorbed water within the fibers, where the intact fibers had more stability with delayed decomposition. The results confirm that the preventive preservation of the studied mummy has to be executed for protecting the mummy from the surrounding environmental conditions.

\section{References}

1. G. Abdel-Maksoud and A. El-Amin, "A review on the materials used during the mummification processes in ancient Egypt," Mediterranean Archaeology and Archaeometry, Vol. 11, No. 2, 2011, pp. 129-150.
2. G. Abdel-Maksoud, E. A. A. Al-Shazly, and A. El-Amin, "Damage caused by insects during the mummification process: an experimental study," Archaeological and Anthropological Sciences, Vol. 3, No. 3, 2011, pp. 291-308.

3. M. P. Colombini, F. Modugno, F. Silvano, and M. Onor, "Characterization of the balm of an Egyptian mummy from the Seventh Century BC," Studies in Conservation, Vol. 45, No. 1, 2000, pp. 19-29.

4. R. J. Jansen, M. Poulus, W. Taconis, and J. Stoker, "High-resolution spiral computed tomography with multiplanar reformatting, 3D surface- and volume rendering: a non-destructive method to visualize ancient Egyptian mummification techniques," Vol. 26, No. 4, 2002, pp. 211-216.

5. R. David, Egyptian Mummies and Modern Science. Cambridge, UK: Cambridge University Press, 2008.

6. Z. Iskander, "Mummification in ancient Egypt: development, history, and technique," In An X Ray Atlas of the Royal Mummies, J. E. Harries, E. F. Wente, Eds. Chicago: University of Chicago Press, 1980.

7. H. A. M. Afifi, "Analytical investigation of pigments, ground layer and media of cartonnage fragments from Greek Roman period," Mediterranean Archaeology and Archaeometry, Vol. 11, No. 2, 2011, pp. 91-98.

8. G. Abdel-Maksoud and A. El-Amin, "The investigation and conservation of a gazelle mummy from the late period in ancient Egypt," Mediterranean Archaeology and Archaeometry, Vol. 13, No. 1, 2013, pp. 45-67.

9. G. Abdel-Maksoud, H. Emam, and N. M. Ragab, "From traditional to laser cleaning techniques of parchment manuscripts: a review," Advanced Research 
in Conservation Science, Vol. 1, No. 1, 2020, pp. 52-76.

10. F. M. Helmi and Y. K. Hefni, "Estimation of deterioration aspects of granitic columns at the Mosque of Al-Nasir Mohamed Ibn Qalawun, Cairo, Egypt," Advanced Research in Conservation Science, Vol. 1, No. 1, 2020, pp. 34-51.

11. Y. Y. Abdel-Aty, H. S. Mahmoud, and A. A. Al-Zahrani, "Experimental evaluation of consolidation techniques of fossiliferous limestone in masonry walls of heritage buildings at historic Jeddah, Kingdom of Saudi Arabia," Advanced Research in Conservation Science, Vol. 1, No. 1, 2020, pp. 16-33. .

12. S. A. M. Hamed and N. M. N. El Hadidi, "The use of SEM-EDX investigations in estimating the penetration depth of preparation layers within wood structure," Advanced Research in Conservation Science, Vol. 1, No. 1, 2020, pp. 1-15. .

13. S. Shoval and Y. Paz, "A study of the mass-gain of ancient pottery in relation to archeological ages using thermal analysis," Applied Clay Science, Vol. 82, 2013, pp. 113-120.

14. A. C. Aufderheide, The Scientific Study of Mummies. Cambridge, UK: Cambridge University Press, 2003.

15. S. L. Forbes, "Decomposition chemistry in a burial environment," in Soil Analysis in Forensic Taphonomy: Chemical and Biological Effects of Buried Human Remains, M. Tibbett and D. O. Carter, Eds. Boca Raton, FL: CRC Press, 2008, pp. 203-223.

16. V. Giuffra, D. Pangoli, P. Cosmacini, D. Caramella, S. Flora, G. Fornaciari, and R. Ciranni, "Paleopathological evaluation and radiological study of 46 Egyptian mummified specimens in Italian museums," Egitto e Vicino Oriente, Vol. 32, 2009, pp. 121-155.
17. M. M. Houck, Identification of Textile Fibers. Sawston: Woodhead Publishing, 2009.

18. D. E. Akin, "Linen most useful: perspectives on structure, chemistry, and enzymes for retting flax," ISRN Biotechnology, Vol. 2013, 2013, pp. 1-23.

19. H. El-Gaoudy, N. Kourkoumelis, E. Varella, and D. Kovala-Demertzi, "The effect of thermal aging and color pigments on the Egyptian linen properties evaluated by physicochemical methods," Applied Physics A, Vol. 105, No. 2, 2011, pp. 497-507.

20. E. May and M. Jones, Conservation Science: Heritage Materials. London: Royal Society of Chemistry, 2006.

21. J. M. Cronyn, The Elements of Archaeological Conservation. London: Routledge, 1990.

22. O. Abdel-Kareem, "Monitoring, controlling and prevention of the fungal deterioration of textile artifacts in the museum of Jordanian heritage," Mediterranean Archaeology and Archaeometry, Vol. 10, No. 2, 2010, pp. 85-96.

23. H. L. Chen, K. A. Jakes, and D.W. Foreman, "Preservation of archaeological textiles through fibre mineralization," Journal of Archaeological Science, Vol. 25, No. 10, 1998, pp. 10151021.

24. E. E. Peacock, "The biodeterioration of textile fibres in wet archaeological contexts with implications for conservation choices," In Proc. Intrecci Vegetali e Fibre Tessili da Ambiente Umido: Analisi Conservazione e Restauro: Atti (Trento, 28-30 Maggio 2003), Incontri di Restauro, 2005, pp. 46-61.

25. J. Jones, T. F. G. Higham, D. Chivall, R. Bianucci, G. L. Kay, M. J. Pallen, R. Oldfield, F. Ugliano, and S. A. Buckley, "A prehistoric Egyptian mummy: evidence for an 'embalming recipe' and the 
evolution of early formative funerary treatments," Journal of Archaeological Science, Vol. 100, 2018, pp. 191-200.

26. D. Beaton, P. Pelletier, and R. R. Goulet, "Microbial degradation of cellulosic material and gas generation: implications for the management of low- and intermediate-level radioactive waste," Frontiers in Microbiology, Vol. 10, 2019, pp. 204-216.

27. C. Nielsen-Marsh, A. Gernaey, G. Turner-Walker, R. Hedges, A. Pike, and M. Collins, "The chemical degradation of bone," in Human Osteology in Archaeology and Forensic Science, M. Cox and S. Mays, Eds. Cambridge, UK: Cambridge University Press, 2000, pp. 439-454.

28. G. Turner-Walker, "The chemical and microbial degradation of bones and teeth," in Advances in Human Palaeopathology, R. Pinhasi and S. Mays, Eds. Chichester: John Wiley \& Sons, 2008, pp. 1-9.

29. A. S. Tatar, O. Ponta, and B. Kelemen, "Bone diagenesis and FTIR indices: a correlation," Studia Universitatis BabesBolyai, Biologia, Vol. 59, No. 1, 2014, pp. 101-113.

30. G. McLaughlin and I. K. Lednev, "Potential application of Raman spectroscopy for determining burial duration of skeletal remains," Analytical and Bioanalytical Chemistry, Vol. 401, No. 8,2011, pp. 2511-2518.

31. C. A. Ratiu, S. D. Cavalu, V. Miclaus, V. Rus, and G. I. Lazarescu, "Histological evidence of novel ceramic implant: evaluation of tolerability in rabbit femur," Romanian Journal of Morphology and Embryology, Vol. 56, No. 4, 2015, pp. 1455-1460.

32. L. Berzina-Cimdina and N. Borodajenko, "Research of calcium phosphates using Fourier transform infrared spectros- copy," in Infrared Spectroscopy - Materials Science, Engineering and Technology, T. Theophile, Ed. Rijeka: IntechOpen, 2012, pp. 251-263.

33. S. Joshi, S. Kalyanasundaram, and V. Balasubramanian, "Quantitative analysis of sodium carbonate and sodium bicarbonate in solid mixtures using Fourier transform infrared spectroscopy (FTIR)," Applied Spectroscopy, Vol. 67, No. 8, 2013, pp. 841-845.

34. M. S. Salil, J. P. Shrivastava, and S. K. Pattanayak, "Similarities in the mineralogical and geochemical attributes of detrital clays of Maastrichtian Lameta Beds and weathered Deccan basalt, Central India," Chemical Geology, Vol. 136, No. 1-2, 1997, pp. 25-32.

35. M. Akerholm, B. Hinterstoisser, and L. Salmen, "Characterization of the crystalline structure of cellulose using static and dynamic FT-IR spectroscopy," Carbohydrate Research, Vol. 339, No. 3, 2004, pp. 569-578.

36. M. Poletto, H. L. O. Junior, and A. J. Zattera, "Native cellulose: structure, characterization and thermal properties," Materials, Vol. 7, No. 9, 2014, pp. 6105-6119.

37. H. G. M. Edwards, E. Ellis, D. W. Farwell, and R. C. Janaway, "Preliminary study of the application of Fourier transform Raman spectroscopy to the analysis of degraded archaeological linen textiles," Journal of Raman spectroscopy, Vol. 27, No. 9, 1996, p. 663-669.

38. H. G. M. Edwards, N. F. Nikhassan, D. W. Farwell, P. Garside, and P. Wyeth, "Raman spectroscopic analysis of a unique linen artefact: the HMS Victory Trafalgar sail," Journal of Raman Spectroscopy, Vol. 37, No. 10, 2006, pp. 1193-1200.

39. C. Chadefaux, A. S. Le Ho, L. BellotGurlet, and I. Reiche, "Curve-fitting mi- 
cro-ATR-FTIR studies of the amide I and II bands of type I collagen in archaeological bone materials," $e$ Preservation Science, Vol. 6, 2009, pp. 129-137.

40. F. Maspero, S. Sala, M. E. Fedi, M. Martini, and A. Papagni, "A new procedure for extraction of collagen from modern and archaeological bones for ${ }^{14} \mathrm{C}$ dating," Analytical and Bioanalytical Chemistry, Vol. 401, No. 6, 2011, pp. 2019-2023.

41. M. Lebon, I. Reiche, F. Frohlich, J. J. Bahain, and C. Falgueres, "Characterization of archaeological burnt bones: contribution of a new analytical protocol based on derivative FTIR spectroscopy and curve fitting of the $v_{1} v_{3} \mathrm{PO}_{4}$ domain," Analytical and Bioanalytical Chemistry, Vol. 392, No. 7-8, 2008, pp. 1479-1488.

42. V. M. Kashkarov, D. L. Goloshchapov, A. N. Rumyantseva, P. V. Seredin, E. P. Domashevskaya, I. A. Spivakova, and B. R. Shumilovich, "X-ray diffraction and IR spectroscopy investigation of synthesized and biogenic nanocrystalline hydroxyapatite," Journal of Surface Investigation. X-Ray, Synchrotron and Neutron Techniques, Vol. 5, No. 6, 2011, pp. 1162-1167.

43. H. G. M. Edwards, D. W. Farwell, D. L. A. De Faria, A. M. F. Monteiro, M. C. Afonso, P. De Blasis, and S. Eggers, "Raman spectroscopic study of 3000year-old human skeletal remains from a sambaqui, Santa Catarina, Brazil," Raman Spectroscopy, Vol. 32, No. 1, 2001, pp. 17-22.

44. K. Chatzipanagis, C. G. Baumann, M. Sandri, S. Sprio, A. Tampieri, and R Kroger, "In situ mechanical and molecular investigations of collagen/apatite biomimetic composites combining Raman spectroscopy and stress-strain analysis," Acta Biomaterialia, Vol. 46, 2016, pp. 278-285.

45. J. D. Fredericks, P. Bennett, A. Williams, and K. D. Rogers, "FTIR spectroscopy: a new diagnostic tool to aid DNA analysis from heated bone," $\mathrm{Fo}$ rensic Science International: Genetics, Vol. 6, No. 3, 2012, pp. 375-380.

46. H. G. M. Edwards, R. H. Brody, N. F. N. Hassan, D. W. Farwell, and S. O'Connor, "Identification of archaeological ivories using FT-Raman spectroscopy," Analytica Chimica Acta, Vol. 559, No. 1, 2006, pp. 64-72.

47. J. Harris, I. Mey, M. Hajir, M. Mondeshki, and S. E. Wolf, "Pseudomorphic transformation of amorphous calcium carbonate films follows spherulitic growth mechanisms and can give rise to crystal lattice tilting," CrystEngComm, Vol. 17, No. 36, 2015, pp. 6831-6837.

48. C. Azemard, C. Vieillescazes, and M. Menager, "Effect of photodegradation on the identification of natural varnishes by FT-IR spectroscopy," Microchemical Journal, Vol. 112, 2014, pp. 137-149.

49. A. Nevin, D. Comelli, I. Osticioli, L. Toniolo, G. Valentini, and R. Cubeddu, "Assessment of the ageing of triterpenoid paint varnishes using fluorescence, Raman and FTIR spectroscopy," Analytical and Bioanalytical Chemistry, Vol. 395, No. 7, 2009, pp. 2139-2149.

50. G. Abdel-Maksoud, H. El-Shemy, and M. Abdel-Hamied, "Investigation methods for evaluating the preservative organic mixtures applied on a late period mummy," Archaeological and Anthropological Sciences, Vol. 11, No. 5, 2019, pp. 1843-1850.

51. A. Boukir, S. Fellak, and P. Doumenq, "Structural characterization of Argania spinosa Moroccan wooden artifacts during natural degradation progress using 
infrared spectroscopy (ATR-FTIR) and X-ray diffraction (XRD)," Heliyon, Vol. 5, No. 9, 2019, p. e02477.

52. M. Regert, S. Colinart, L. Degrand, and O. Decavallas, "Chemical alteration and use of beeswax through time: accelerated ageing tests and analysis of archaeological samples from various environmental contexts," Archaeometry, Vol. 43, No. 4, 2001, pp. 549-569.

53. G. Scorrano, C. Mazzuca, F. Valentini, G. Scano, A. Buccolieri, G. Giancane, D. Manno, L. Valli, F. Mallegni, and A. Serra, "The tale of Henry VII: a multidisciplinary approach to determining the post-mortem practice," Archaeological and Anthropological Sciences, Vol. 9, No. 6, 2017, pp. 1215-1222..

54. M. D'Elia, G. Gianfrate, G. Quarta, L. Giotta, G. Giancane, and L. Calcagnile, "Evaluation of possible contamination sources in the ${ }^{14} \mathrm{C}$ analysis of bone samples by FTIR spectroscopy," Radiocarbon, Vol. 49, No. 2, 2007, pp. 201-210.

55. T. Kubota, A. Nakamura, K. Toyoura, and K. Matsunaga, "The effect of chemical potential on the thermodynamic stability of carbonate ions in hydroxyapatite," Acta Biomaterialia, Vol. 10, No. 8, 2014, pp. 3716-3722.

56. M. Sari and Y. Yusuf, "Synthesis and characterization of hydroxyapatite based on green mussel shells (Perna viridis) with calcination temperature variation using the precipitation method," International Journal of Nanoelectronics and Materials, Vol. 11, No. 3, 2018, pp. 357-370.

57. N. S. Chickerur, M. S. Tung, and W. E. Brown, "A mechanism for incorporation of carbonate into apatite," Calcified Tissue International, Vol. 32, No .1, 1980, pp. 55-62.

58. A. Sillen and R. LeGeros, "Solubility profiles of synthetic apatites and of modern and fossil bones," Journal of Archaeological Science, Vol. 18, No. 3, 1991, pp. 385-397.

59. Y. Gaillard, A. Mija, A. Burr, E. Darque-Ceretti, E. Felder, and N. Sbirrazzuoli, "Green material composites from renewable resources: polymorphic transitions and phase diagram of beeswax/rosin resin," Thermochimica Acta, Vol. 521, No. 1-2, 2011, pp. 90-97.

60. G. Ma, D. Yang, and J. Nie, "Preparation of porous ultrafine polyacrylonitrile (PAN) fibers by electrospinning," Polymers for Advanced Technologies, Vol. 20, No. 2, 2009, pp. 147-150.

61. A. P. Dimitrakopoulos, "Thermogravimetric analysis of Mediterranean plant species," Journal of Analytical and Applied Pyrolysis, Vol. 60, No. 2, 2001, pp. 123-130.

62. S. F. Pop and R. M. Ion, "Thermal analysis of the chemical weathering of chalk stone materials," Journal of Optoelectronics and Advanced Materials, Vol. 15, No. 7-8, 2013, pp. 888-892.

63. F. Leach, J. Davidson, G. Claridge, G. Ward, and J. Craib, "The physical and mineralogical characteristics of pottery from Mochong, Rota, Mariana Islands," in Islands of Inquiry: Colonisation, Seafaring and the Archaeology of Maritime Landscapes, G. Clark, F. Leach, and S. O'Connor, Eds. ANU E Press: Australia, 2010, pp. 435-452.

64. D. L. Morgado and E. Frollini, "Thermal decomposition of mercerized linter cellulose and its acetates obtained from a homogeneous reaction," Polimeros, Vol. 21, No. 2, 2011, pp. 111-117.

65. T. Deviese, M. Colombini, M. Regert, B. H. Stuart, and J. P. Guerbois, "TGMS analysis of archaeological bone from burials of the late Roman period," Journal of Thermal Analysis and Calorimetry, Vol. 99, No. 3, 2010, pp. 811-813. 
66. M. Figueiredo, A. Fernando, G. Martins, J. Freitas, F. Judas, and H. Figueiredo, "Effect of the calcination temperature on the composition and microstructure of hydroxyapatite derived from human and animal bone," Ceramics International, Vol. 36, No. 8, 2010, pp. 23832393.

67. A. Heredia, M. Colin-Garcia, M. A. Pena-Rico, L. F. L. A. Beltran, J. Gracio, F. F. Contreras-Torres, A. Rodriguez-Galvan, L. Bucio, and V. A. Basiuk, "Thermal, infrared spectroscopy and molecular modeling characterization of bone: an insight in the apatitecollagen type I interaction," Advances in Biological Chemistry, Vol. 3, 2013. pp. 215-223.

68. B. Wunderlich, Thermal Analysis of Polymeric Materials. Berlin: Springer, 2005. 